$7^{\circ}$ Simposio Internacional de Investigación Multidisciplinaria / Ciencias de la Salud 7th Internationalm Symposium on Multidisciplinary Research / Health Sciences

\title{
CS-14 Prevalencia de vaginosis bacteriana y factores asociados en mujeres de edad reproductiva
}

\author{
Prevalence of bacterial vaginosis and associated factors in reproductive age women \\ Debby D. Ramírez-González*, Diego del Valle-Urrutia \\ Universidad de San Carlos de Guatemala, Guatemala
}

*Autor al que se dirige la correspondencia: dayan3891@gmail.com

\section{Resumen}

T a vaginosis bacteriana (VB) es una de las principales causas de morbilidad en mujeres en edad fértil. El ob_jetivo fue determinar la prevalencia de VB y factores asociados en mujeres de 15-45 años, que consultaron a unidad mínima de salud Tres Pinos, a los puestos de salud San Nicolás, Chispán, El Guayabal y el centro de salud de Estanzuela, Zacapa, durante febrero de 2016. Se realizó un estudio descriptivo transversal en 444 mujeres a quienes se les hizo una entrevista según un cuestionario estructurado y un examen cérvico-vaginal, prueba de $\mathrm{KOH}$, medición de $\mathrm{pH}$ vaginal, búsqueda microscópica de células clave y morfología del agente etiológico. La prevalencia de vaginosis bacteriana fue del 78.15\% (IC 95\% 74.23-82.07\%) y la media de edad afectada fue de $33 \pm 8$ años. Los factores asociados fueron: Escolaridad primaria, 182 (40.90\%); no tener relaciones sexuales durante la menstruación, 307 (69.14\%); planificación familiar, 132 (29.73\%). De las mujeres que presentaron vaginosis, 193 (43.46\%) cumplieron con los criterios de Amsel. Se realizó el cálculo de Chi 2 y Odds Ratio (OR), sin embargo, no se encontró asociación estadísticamente significativa entre las variables estudiadas. En Estanzuela, la VB representa una de las principales causas de morbilidad debido al inadecuado diagnóstico y tratamiento, reflejado así una alta prevalencia y contribuyendo a las múltiples complicaciones gineco-obstétricas en la población guatemalteca.

Palabras claves: Vaginitis, flujo vaginal, salud reproductiva

\section{Abstract}

$\mathrm{B}$ acterial vaginosis (BV) is one of the major causes of morbidity in women of childbearing age, the main objective was to determine the prevalence of BV and associated factors in women between 15-45 years who consulted Minimum Health Unit Tres Pinos, health posts San Nicolás, Chispán, Guayabal and the health center of Estanzuela, Zacapa during February 2016. Transversal descriptive study was conducted in 444 women interviewed with a structured questionnaire and a cervico-vaginal examination, $\mathrm{KOH}$ test, vaginal $\mathrm{pH}$ test, microscopic search of clue cells and morphology of the etiologic agent. The prevalence of bacterial vaginosis was $78.15 \%(95 \% \mathrm{CI}$ $74.23 \%-82.07 \%$ ) and the main age affected $33 \pm 8$ years. Factors associated with VB were: Elementary schooling, 182 (40.90\%); not having intercourse during menstruation, 307 (69.14\%); family planning, 132 (29.73\%). 193 (43.46\%) women who had vaginosis, met the Amsel criteria. Chi 2 and Odds Ratio (OR) were calculated, however, no statistically significant association was found between the variables studied. In Estanzuela, BV represents one of the main causes of morbidity due to inadequate diagnosis and treatment, thus reflected in its high prevalence and contributing to multiple gynecological obstetric complications in the Guatemalan population. There was no statistically significant association between the variables studied. 